\title{
Overcoming prejudices in emancipatory education: The remaining group
}

\section{Tentando desfazer preconceitos em uma educação emancipatória: o grupo dos remanescentes}

\author{
Angela Maria Pires CANIATO \\ Michele Aparecida CASTRO' \\ Karina Quilice MARTINELLI' \\ Lara Hauser SANTOS \\ Sarah Gisele SILVA'
}

\begin{abstract}
The Remnant Group was one of working parties of the project "Phoenix: Challenge in the rebirth of subjective citizenship". The group consisted of young people who integrated a government educational institution, current called assistant philanthropic institution, in which they could not be members after their $18^{\text {th }}$ birthday. Consequently, they had to return to the streets. Participating research was the methodology employed and interventions with these young people aimed at re-signifying their experiences which had been shaken by self-aggressive identifications. Debates tried to de-mystify biases linked to their social condition of poverty. The young people repeated in their activities the danger labels that society imposed upon them. The mediation of the dangerous social class concepts, accusation category and the internalization of social violence was undertaken. They became aware of the necessity of protecting themselves from society and the State apparatus. In our dialogues it was agreed that the manifestation of detailed intimate feelings was not allowed. Different procedures were used and the repeated themes consisted of social violence in its most diverse nuances. The most important difficulty comprised the management of the intensity of the consolidation of social stigmas internalized by the young people to whom were attributed the connotations of dangerousness and evilness.
\end{abstract}

Uniterms: Education; Intervention studies; Prejudice; Social control; Social discrimination; Social violence.

\section{Resumo}

O Grupo dos Remanescentes foi uma das frentes de atuação do projeto "Phenix: a ousadia do renascimento da subjetividade cidadã". Era composto por adolescentes que participaram de uma instituição educacional pública, hoje instituição assistencial filantrópica, na qual os adolescentes não poderiam continuar depois que completassem dezoito anos - estavam, portanto, na rua, antes de ingressarem no nosso projeto. A metodologia utilizada foi a da pesquisa participante e as intervenções junto a esses adolescentes tinham como objetivo a ressignificação de vivências atravessadas por identificações autoagressivas. As reflexões buscavam a desmistificação de preconceitos vinculados à sua condição social de pobreza. Em suas práticas, os jovens reiteravam o rótulo de periculosidade que a sociedade Ihes impõe. Trabalhou-se com a mediação dos conceitos de classe perigosa, categoria de acusação e internalização da

\footnotetext{
$\nabla \nabla \nabla \nabla$
}

1 Universidade Estadual de Maringá, Curso de Psicologia, Departamento de Psicologia. Av. Colombo, 5790, Zona Sete, 87020-900, Maringa, PR, Brasil. Correspondência para/Correspondence to: A.M.P. CANIATO. E-mail: <ampicani@onda.com.br>. 
violência social. Foram alertados sobre o quanto legitimavam a necessidade de vigilância da sociedade e do Estado. Nos diálogos, foi mantido o acordo de não permitir a exposição de suas intimidades. Foram utilizados diferentes procedimentos e a temática reiterada era a da violência social em suas diversificadas nuanças. A maior dificuldade foi lidar com a intensidade de cristalização dos estigmas sociais internalizados por esses adolescentes, afetados pelas conotações de periculosidade e malignidade.

Unitermos: Educação; Estudos de intervenção; Preconceito; Controle social; Discriminação social; Violência social.

This paper addresses the systematization of the intervention performed on the Group of the Remnants, one of the operations of the "Phenix research project: the daring of the citizen subjectivity renaissance", approved by the Ethics Committee in research of the Universidade Estadual de Maringá (UEM), opinion no 071/2002, in 2002 and all the participants signed a free informed consent prior to their inclusion in this sample. Its development starts at the práxis and has the Critics Theory of the Frankfurt School as epistemological orientation, mainly the Theodor Adorno work, and as foundation it has the view that men are the producer and the produce of the culture in which they live (Leontiév, 1978) The project is structured as qualitative research (González Rey, 2005) therefore postulating the non - neutrality of science. The practice is effective through partnerships between the Universidade Estadual de Maringá and the Maringá (PR) institutions attended by impoverished teenagers, the focus of the research. Interventions occur once a week through educational and cultural activities, based on the demands raised together with the young participants of the project. For its realization there are fifteen students of the UEM Psychology Course and six Post Graduation in Psychology students (PPI-UEM).

The methodological approach is guided by participant research and militant observation, which according to Thiollent (1981) and Brandão (1981; 1984), has as one of its targets, to question the ideological principles that support society and the production of knowledge. Starting with the chosen method, the searched group is not seen as a mere research subject, but as one of its participants, and it performs both the learning action and the transforming knowledge and social reality action. Within this methodology the author of the study subject is inverted: the researcher is no longer the one who delimits, but the population - target that proposes what shall be learned at the first meetings or when some meaningful episode is lived by those teenagers: they are the requirement issues.

The "praxis" concept is used within this methodological orientation to designate the intervention, understood as "... intentional men activity that aims, ultimately, at men's well-being" (Carone, 2003, p.2). "... Praxis is a continuous improvement activity of human beings and society. The later could be called "formative activity"' (Carone, 2003, p.4). The formation is reciprocal under this point of view, respecting the specificities of each subject and their role in the research.

The second part of the making of the Project is done after the survey of the requirement issues that correspond to theoretical-methodological preparation of scholars and master participants in order to support the issues that constitute the practical part, together with the teenagers. Such preparation is effective through three activities: (1) bibliographic research and group orientation of topics connected with the requirement issues; (2) systematic reading of the work of Freud and (3) guided studies of the main concepts of the work of Theodor Adorno together with the scholars and masters participants.

It is also understood that it is not easy for young university students to realize the theoretical, ethical and political demands of this research process, especially front to the de-politicization that follows the educational process of nowadays youngsters. For this reason it is highlighted the need to provide them with theoretical-methodological framework that broadens their skills to meet and act with the psychosocial problems experienced with those teenagers. Accordingly we try to provide them with information about the construction of the modern globalized states (Agamben, 2007; Bauman, 1998; Mariotti, 2000) in order to allow them to better understand social class differences and the social violence that arises from those who hold economical-political hegemony. 
Utopia, which is the conductor line of our praxis (Carone, 2003), is the hope that the phoenix bird legend may be updated with this population ${ }^{2}$ through the discussions we hold with teenagers. The wish of each participant is that we may, in this desert we live in, be like aromatic leaves around each person that feels they are succumbing and that we, under the light of reflection, may be able to warm and end the apathy caused by fatalism (Martin-Baró, 1987), so that the rebirth of the individual-subject be possible.

The objective of these interventions is to develop, together with the teenagers, reflexive thought based on an immanent critique, so those youngsters who live in adverse social conditions may become agents of transformation in social reality. They are propositions that Adorno (1995) names "Emancipatory Education". This means that such reflections, about the issues that keep them linked to stereotypes, enable the development of a critical conscience consistent with the rebuilding of a collective solidarity and a crescent politicization of their everyday lives.

Political perspective is the main concern that rules this Intervention - Research Project, and is based on the statement that impoverished social classes live under psychosocial violence, once they are exposed to marginalizing actions and coercions in their public and private lives. Often exposed, they show the psychosocial provocations of which they are target through challenging action of higher or lower destructive degree which leads them into becoming easy preys of the police repressive actions.

Maybe because of that this population is being considered a "risk population", and is seen as threats to the dominant status quo (Caniato, 2003). However, exposing this population to the prejudice expressed in the "accusation category"(Velho, 1987) and in the injury of "dangerous classes myths" (Coimbra, 2001) makes such individuals a vulnerable target to the development of the "culpability feeling" through the internalization of this social violence (Freud, 1930/1981). Under such self-punishment those teenagers are stopped from identifying the social violence that abuses them, therefore preventing them from developing some criticism and protection towards themselves and the oppressive conditions in which they live, making them accomplices of this social oppression. They become easy preys to such stereotyped standardizations produced by society (Adorno, 1986a). Even more serious - those teenagers end up justifying such stereotypes as they enter a life exposed to dangers that many times culminates in many acts identified as "heroic".

In the building of this critic analysis that the population makes of their reality, researchers send feedback all through the investigation process, helping the researchers to organize their ideas. Moving toward this direction of the discussed themes, an analysis of the society contradictions that are expressed in the reality and in the actions of men, contrasting what is and what should be, searches knowledge closer to reality in order to understand links between daily life and logic and the dominant forces of social macrostructure.

It is important to be conscious of the facts, gestures, stories and "images" of the things that are present in daily life and that influence the lives of the individuals and that they cannot be alienated within them. This process, however, is psychological and depends on how much we want to question our certainties, concepts, virtues or faults, allowing the transformation to happen from the inside. The clinic aspect of this paper lives there. It is not easy, but it is believed that in the end, the population, and the researcher will be able to think in a way that critically reveals some aspects of the reality in which they are inserted.

\section{Telling the story of the vicissitudes of the remnant group: A journey through their swirls}

The Remnants group appeared in September 2002 to meet adolescents that had participated in other activities of the educational public institution where "Phenix..." started its interventions. They could no

\footnotetext{
$\boldsymbol{\nabla} \nabla \boldsymbol{\nabla}$

2 For better explanation: phenix was a fabulous bird that according ancient legends was unique in its kind. It lived, for many centuries, in the harsh deserts of Arabia. When it felt death approached, it built a nest of aromatic plants to the sun's rays and set fire to consume in it. From the marrow of its bones a worm was born, which turned into another phenix.
} 
longer attend that entity for having reached the age of eighteen, and the institution could no longer support them either.

Once the public educational institution and later the philanthropic Assistance Institution mentioned cared for children and adolescents, the latter have just lost their protection as they turn eighteen, when they are "abandoned" and exposed to the world of labor, which does not enable jobs for everyone (Martín \& Schumann, 1999). Most of them no longer have any public institution that might work as a reference. This way they are exposed to biased social injunctions, to which impoverished classes are subjected. Within this context, the violence of social stigmatization is empowered, for jobs intercepted by new work organizations become rarer and rarer on the market. It is important to say that those young people, as all human beings, need protection, in other words, the parameters of reference that the social/educational institutions could offer to them. Besides social abandonment in poverty, those youngsters are left on their own, and are not being prepared to face adult life; the State does not provide them with educational assistance after they turn eighteen.

The formation of the Group of the Remnants was attributed to P., a teenager that attended the public educational institution for many years and had already participated in the intervention of the Phenix together with the young agents group. Caniato et al. (2002). Since the beginning of 2002, the teenager insisted on a continuity of the work that she had liked a lot. At that time she had already turned 18 and had been disconnected from the institution. She was pregnant and had no support from the child's father, besides not having found a job.

Other friends of hers were in the same situation. They would always come near the institution building and spend a great part of the day there; they had already asked the institution about the possibility of attending it again. In a dialog between the Phenix members and the pedagogical coordinator it was stated that the psychosocial worries regarding those young people were similar, once they were in a helplessness and vulnerable situation. It was decided that a group, different - regarding participation - from the others assisted by the institution, would be open: all but the 572 Remnants, participated, every day, in different pedagogical and sportive activities offered by the institution, and those who had already turned 18 would attend the institution only once a week to meet with Phenix academics.

The denomination given to the group was "The Remnants", thanks to the criterion established for its formation, in other words, adolescents who had already participated in any of the activities offered by the public educational institution. When the group was named "Remnants" there was no etymological understanding of the word that was being used to qualify those adolescents. At the moment of this theoretical systematization, it was confirmed that even though there was no etymological clarity of the concept "remnants" when the group was created, social discrimination to which such adolescents were and are still exposed to, was already visible. According to the etymological dictionary (Cunha, 1982), the word remnant comes from Latin "remanescentem" and means second, remaining, the one that is left, rest or what is left over. Paradoxically, however, remaining also means those who resist, the one who is left out of all the exclusionary social process.

It was precisely in this situation of remainder that those teenagers were at the institution, and because of their poverty, it should be observed that the same occurred in various areas of their lives in society. However, it is not up to one to say that such teens are on the margins of society, because in fact they are the individuals who do not have access to social goods necessary condition for maintaining the status quo (Sawaia, 1999). No one can say, however, that such teens are on the margins of society, because in fact they are the individuals who do not have access to social goods, a necessary condition for maintaining the status quo (Sawaia, 1999).

Not everybody at the institution shared the same worries with Phenix and with the pedagogical coordinator, regarding the Remnants. According to information that covertly began to reach the Phenix academics, there were, in the institution, various forms of discrimination against those young people. They stated that it would be desirable that they should not return to the institution and therefore, a group with them should not be formed. Thus, with the support of the research of (Coimbra, 2001) it was understood that the image of criminality is identified as those offenses committed by impoverished social strata" (p. 59): in 
other words, poverty is criminalized. However, there is no doubt that this categorization is based on prejudice to be "... deconstructed [as] such linear interpretations ...are ultimately looking for 'scapegoats', ie, any Machiavellian culprits responsible for certain issues" (Coimbra, 2001, p.74).

The insults they were subjected to were transmitted to the Phenix academics by the teenagers themselves, and at the beginning they were understood as rumors. They complained they were called lazy, accused of being always involved in street fights, drug users and involved in prostitution; finally they were considered criminals. They could not eat or play soccer with the other teenagers. The principal demanded that their entrance and exit be done through a particular gate, apart from the other teenagers and accompanied by a Phenix academic so that they would not be in touch with the other young people. After some time, the day and time of the weekly meeting was changed to Friday from 4:00 to 6:00 PM, a day and a time when other teenagers were not at the institution. The claim of the present Director was that they were already "criminal liability" (sic) and that if any timely act hurt another teen in the institution, it would surely be accounted responsible by the families of those young people, with no legal support to defend itself (Estatuto da Criança e do Adolescente, 1990).

The fact that those young people, without their approval, be idle and institutionally marginalized is interpreted, by many, as a characteristic that individualizes poor groups. As Coimbra (2001, p.105) points out, .... the relationship among vagrancy/idleness/ indolence and poverty and poverty and hazardousness/ violence/criminality has been established, crystalized". The Group of the Remnants has, therefore, brought within its formation, the mark of social stigmatization with the rejection of the institution that once housed them before they were 18 - because it is, supported by the state, released from the responsibility of taking care of adolescents who are over 18 (Brasil, 1990).

The meetings began in September 2002 and continued until August 2004, with the acquiescence of the pedagogical coordination of the public educational institution that left in early 2003, since the institution was privatized by the state. When the first board of the assistance philanthropic institution took over, the Phenix academics suffered some subtle restrictions, which were made to the Remnants. However, such embarrassing situation did not last long and was reversed as soon as the new pedagogical coordination of the assistance philanthropic institution took over and inserted the Group of Remnants into a community action programs of that institution.

Because those teenagers belong in an impoverished social class and are subject to the same social injunctions, the issues brought to the group by most of them were the same. The young people that belonged in the Group of the Remnants brought their stories of having transgressed limits, which they actually have, because they venture in those situations of death risk, either because of omnipotence, which deceives many, or because they are immersed in nowadays ideologies which present a person with no limits. Also, there were many judicial sanctions currently applied to young poor people, veiled and distorted by the idea of "socio-educational measures" proposed by the ECA (Brasil, 1990). Against this social inversion, specifically the ones of the stigmatizing nature of these young people, Bourquin $(2003$, p.4) points out that:

Judicial protection measures should not exclude minors from the possibility ofliving their adolescence. Juvenile delinquency is often just a passing phenomenon aggravated by serious social and cultural problems. The juvenile offender, more than any other, needs to be welcomed, listened to, trained, given a job, as well as learn the limits and boundaries of places that are not places of exclusion.

This author is benevolent in his criticism of the allocation of malignancy for those adolescents, for the qualification of the crime, once attributed to young people who committed some social infraction is no longer used and has been replaced by covered criminalization expressed in the definition of ECA (Brasil, 1990) of "adolescents in conflict with the law", which is much more denigrating

The group protagonist, (P.), cited above, was the victim of institutional reproduction of social stigmatization. Although P., on her own, has been the protagonist of the constitution of the Remnants Group, after the fourth meeting she started being away and frequently absent. Participants were asked in an attempt to know the reason why P. would not come. Initially, the teenagers said that her mother did not allow her to 
attend the meeting due to the presence of another teenager in the group that used to harass her. Scholars came to look for her at her home to understand what had caused her leaving, which was strange - in view of her commitment for the group to be created - and bring her back to the group. After that, some of the participants reported that some member of the coordinating institution had "asked" P., to no longer attend the institution, for she would set a "bad example for the other students due to the fact that she was single and expecting a baby" (sic).

A tour to celebrate the end of the year, and the activities developed by the institution was taken in December 2002. Many of the other groups had already gone on that tour to the lake near the city. Their enthusiasm was accompanied by the frustration of the Group of the Remnants; but there was not a planning for them to participate in the tour as well, which only happened because of the requests of the Phenix scholars. Many educators, students from other groups and two scholars of the Project, "who later became responsible for the Coordination of the Institute to take care of the Group of the Remnants", (sic) were present in the tour. One of those scholars was also a target, on the tour, through words, of an attempt of seduction that came from one of the institution employees, whom $P$. had already pointed as the father of the baby she was expecting.

Interestingly, now the roles and responsibilities for malignancy have been inverted... resuming the previous episode, the member of the Phenix was called by the principal of the philanthropic assistance institution to determine the segregation of the Remnants entrance and exit - from the institution through gates that were apart from the others. Well, to justify such segregation it was said that the youngsters were sexually harassing the institution students... . That Principal was a lawyer and must have known that the attribution of "sex offenders" to those teenagers was wrongly used, for according to Article 216 of the Penal Code, (Brasil, 2001), sexual harassment is an aggression to the intimacy and dignity of a person in an asymmetric relation between the victim and the agent who is based on abuse of power.

It was a foolish way to give them a negative and defamatory nickname, so, not to assume the stigmatization, for such legal sanction cannot be applied to the horizontal relationship among teens. Actually there was the creation of "scape goats", with the projection of social malignance over those adolescents who already carried the stigma of other criminalizing prejudice.

Besides, at the meetings with the group of the Remnants held in January 2003, some of the young people of the group gave information regarding intimate involvements between employees and some students from the institution, encounters that took place at "parties" at their places according to the testimony of one of the scholars of Phenix, who was also sexually harassed by that employee; is such crime to be punished? It is sad... but the stigma of being a "bad example" was put on P. which justified her disguised expelling from the Group of the Remnants. According to Velho (1987, p.59):

...the existence of an identifying moral order of a particular society makes the deviator work as a limiting factor of frontiers, a differentiator symbol of identity, which allows society to discover itself, to understand itself through what it is and what it does not want to be (emphasis added).

The label "bad example", front to the other students of the institution, has a stigmatizing and excluding moral perversion regarding P. Furthermore, because it is an assistance institution, some ethical cowardice and pedagogical inability to deal with the problem is reflected at allowing the staying of that immoral employee who went on disrespecting even scholars. The attribution of such label to P. shows the teenager as an "evil carrier", who should be kept away from the institution. The way the institution dealt with P.'s pregnancy corroborates, again, the stigmatization against those young people. The aim of such attribution is to silence and/or ignore them, so that in silence they cannot report the contradictions of society and the violence imposed to them (Caniato, 2008).

The imposing of a "reporting category" (Velho, 1987) has not happened only to the referred protagonist of the Remnants Group, but is present in the lives of all the other participants. It is about a socially built process, which is not restricting to the institutional sphere. It pursues and makes it, at all times, difficult to insert those young people in society in a critical and dignified way. 
As systematizing happened, it was understood that because it was necessary to ask the institution coordination for permission to allow those teenagers to participate in their activities, (such as playing soccer during the breaks, eating at the institution, etc.), the Phenix participants worried about protecting them from possible humiliation, once they considered themselves segregated. In the end, the continuity of social discrimination reproduction, by the institution until a few months after the establishment of the philanthropic assistance institution, was lessened due to the fact that Phenix asked, on teenagers' behalf, about their participation in the activities offered by the institution. While it was tried not to let the segregation practices, reproduced by the institution, have worse disruptive effects on the teenagers, the coordination remained indifferent to the assessment it produced.

With such understanding of the process developed with the teenagers of the Group of the Remnants, the main goal was to work on the reinterpretation of their perverse identification with prejudice that was socially imputed to them. It is evident that they expressed themselves through pseudo individuation (Adorno, 1986a), through lack of selfrespect and through unconscious complicity with evil prejudiced attributions that are imposed/attributed to them while in an impoverished class (Velho, 1987; Coimbra, 2001). Actually, the teenagers showed their fragility because they were submitted to this social violence. Certainly, institutional helplessness made it easy for them to be submitted, to become easy prey to be manipulated and captured by the destructiveness of the identifications with the evil attributes imposed to them by society.

\section{Entering the adventures of the remnants under experienced social violence}

Such aspects were identified, already in the first meeting, once the issues and demands that guided the intervention were raised. At that moment it was possible to realize how immersed in social violence they were, for the issues had been placed, from the beginning, around this topic, and were present in all other meetings and all through the intervention process. All meetings are reported in what was called "Anthropological Diary". The issues raised by them were discussed through films and television programs, dramatizations, dynamics, texts and posters and the interpretations were supported by concepts such as: "internalization and social violence" (Freud, 1930/1981; Adorno \& Horkheimer, 1985); "accusation category"(Velho, 1987); "dangerous classes" (Coimbra, 2001); "cult to a hero" (Caniato, 1997), the omnipotence of social demand; "suffering at work" (Dejours, 1999), the destruction of subjectivity through identifying models conveyed by the media (Abeche, 2003; Caniato, 2003), "stay with" (Chaves, 1997) and "standardization" of subjectivity (Adorno, 1986a).

At first, the standing hypothesis was that the insistence on the same topic was because of the significant turnover rate of the members of the group through the intervention process. It was known, however, that the social violence issue followed the lives of each and every teenager of the group... All involved people, at different times, entered the Group, reported experienced situations that involved daily risk and danger. The information was similar to the experience already reported in the testimony of the other members of the group. This way, the central topic, violence, related to such experiences was taken up and discussed repeatedly.

The exposition of their lives to death was told in an ordinary way, even hilarious. When there was no explicit violence in the narrated facts, they aggregated it.

That can be seen in the report of a teenager, who, laughing, told about having been "stabbed" (sic) on the forehead, which was covered by a Band-Aid. It was stated that it was a lie; however, its meaning, regarded as bravado, gave the woman a prominent status in the group. There were only a few bruises and scratches due to family conflicts that she did not have to hide. Such simple curative would not be appropriate for a knife wound. What called the attention was the fact that the happening, which involved physical violence, was reported the way the teenager did: showing off as glorious, convinced that she was the "tragedy" heroin.

It was tried to show the group how exposed to danger and to death, which they challenged, they were. The violent way of living they were treating as ordinary and worse, considering glamorous, dealing with those experiences in a frivolous way, once they were not 
differentiating life from death, and were, in addition, transforming death into a show, was pointed out.

Following the procedures of seeking clarification for demands and searching for elements for discussions about social violence, it was offered to the group a trip to the movies to watch the film "City of God" on $10 / 16 / 2002$. When they arrived at the theater, it was noticed that the group was observed by the people who were at the mall, where the movie was shown. The teenagers were very excited about the atypical situation they were living at that moment. As they entered the movie theater the lights had already been turned off and the film showed trailers. When they went up the stairs in the room, one of the teenagers tripped over something and the others laughed, which made a lady shout:"shut up, you bunch of vagabonds" (sic). Front to the offense the teenager reacted verbally. Nevertheless, it did not end because the woman insisted on opposing to their stay in the movies, and gave birth to a series of events that ended in physical fight, police and the expelling of the teenagers from the movie theater. The happening ended in the women's police office and all through the procedures, the teenager was ironic and disrespectful towards everybody involved: police officers, scholars, movie theater manager, and deputy. She kept on attending the Group of the Remnants for a while. Later she did not show up to the meetings and nobody knew how the story ended. Many meetings of the group were dedicated to the discussion of what had happened at the cinema.

Sometime later, when the scholars were arriving for a meeting with the Group of the Remnants teenagers, a member of the pedagogical team of the Philanthropic Assistance Institution called them for a word in their room and the presence of the scholars was demanded. At that moment the order came: the Remnants could only enter the institution on meeting days, in other words, only on Wednesdays from 1:30 to 4:00 PM. The decision of the team was to order the entrance and the exit of the Remnants, only with the presence of scholars, only on the day and time allocated for the intervention and through a different gate, apart from the other learners. Once the scholars had no autonomy to do a research in the institution without consent, it was regarded as an attempt to expel the teenagers from this protective shelter. The situation remained the same until the change of the management, when the young people were awarded by the community care program, finally establishing a bond of belonging.

At the meetings with the Group of the Remnants, scholars were watchful at capturing everyday attitudes and justifications used to think and act destructively as they used to. They tried to examine their adventures and analyze the violent psychosocial meanings of their experiences. There was always the intention to help them to reorganize their lives, by discussing with them ways to have social insertion in a critical way, to better protect and to free them from the malignancy and prejudice that had been socially imposed to them.

\section{Deeper understanding of the damage caused by internalized social prejudice: Destroyed subjectivities}

Phenix follows the conception that the human being is the "culture being", that everything related to human subjectivity must be analyzed eminently and always under the light of the social, historical and ethic context of each period, and linked to the psychosocial issues that are pertinent to them (Leontiév, 1978). It was evident that the work with the Group of the Remnants that, in contemporaneity, Culture - ethos of men had lost its people's protective dimension and had turned into the main instrument of social violence because it had been transformed into cultural industry (Adorno, 1986a).

Such transformation is related to the attention given to economic interests of the hegemonic social class, for nowadays society is at the service of Capital and not at the service of men (Crochik, 2005). Such inversion perverts the protection objective of Culture, as it was studied by Freud (1930/1981), serving as the main instrument to impose ideology and identification models that correspond to the maintenance of the status quo. Violence is, therefore, the acting instrument together with the individuals, because of the production of knowledge and objects of pleasure, which have been withdrawn from men and deposited on money and consumer goods, inherent to the building of ideology. Having money, in this case, is more valuable than being a person. Those "ideas", however, are transmitted to individuals under intense seduction and glamour (Lucchesi, 2002). They are convinced to 
"interpret them" as real "designations" to be followed, as if they had originated in them and appropriate to the whole world. Such inverted and dislocated appropriation of thought and desires of people for goods and money makes each person and everybody subordinate and accomplices to those abusing suffered actions. They start to be reproduced by individuals as a prize to be shown off.

However, there is no doubt that they are facing a strong indication that cultural industry acts on people in a way to weaken their superior psychological structure (principle of reality), weakening their real possibilities of discernment and choice. Men may reflect and "... discernir lo interior (perteneciente alyo) de lo exterior (originado por el mundo)..." (Freud, 1930/1981, p.3019, italics added); however, under the kingdom of cultural industry, they are at the mercy of primary processes, (unconscious/'oceanic feeling'), in other words, to sheer principle of pleasure, to total irrationality of the full discharge of disproportional drives, lacking any care/ preoccupation with conditions imposed by the external world. The ideology to suppress and repress all the data related to reality, provides an illusory understanding of this reality, because, besides presenting the objects partially and distorted, thus imposing its "diabolical constructions" as if they were truths (Cohn, 1986).

The deficient development of higher psychological structures, developed in relation to culture (Freud, 1930/1981), if executed under the sign of symbolic violence of ideology - to provide illusory "knowledge" about reality - brings therefore, damage in the apprehension of the real and imposes severe damage to the process of self-identification (individuation). Individuals, besides becoming passive recipients, are devoid of relational capacity of thought for being "banned"from having access to all constituent objects. The deception and lies (Caniato, 2007) are their inseparable companions in all areas of their lives. Wouldn't this installation of failure, in men, the driving force that sustains the exclusionary way of living of most individuals?

It is within this rapist process that culture loses not only its function of support to men and to become a disruptive powerful force of the subjective attributes of individuals, but also comes and devours the integrative force of the relationship between men. The "ideas" disseminated in a misleading way (ideology), deform the ability to grasp and to understand human thought. The identification of such concealed violence becomes difficult. It is seized only by the irrationality of the 'oceanic feeling' (Freud, 1930/1981), consistent with the symbioses of individuals among themselves and the maintaining of links regressed from the individual with themselves, affecting interpersonal relationships and institutions of Culture. If human thought could be driven into service of force subject of men, it would be focused on building a Culture of men and for men effectively (Adorno 1985; Adorno \& Horkheimer, 1947/1985).

Within the neoliberal context in which the present Culture is being managed, the Market is the only ruler, both economically and socially (Guinsberg, 2001).

It is easy to recognize how mean the identifying models induced by the media are. In modern times they work as real seduction and capture strategies (standardization) of subjectivities. They do not excel because of the individual in their humanity and autonomy, but the only and exclusive interest on them is as a consumer. The act of consumption becomes the most valued. Men, thus, in the illusion of being the subject of today society, do not realize that the action of the industrial culture is just a passive object of the same.

Through cultural industry, or maybe the Desire industry, even idleness is commercialized. That can be exemplified by the article "Pleasure and Danger"(Shelp, 2003), in which there is the exaltation of adventure and extreme sports as a possible way to let go, in their free time, the instinctive reactions that are not repressed and not-integrated like anger. The substitutive reward is to give men the illusion of omnipotence. It is a routine to turn on the television and face programs whose main theme is extreme sports and their doers, considered as "adrenaline heroes". The building of current subjectivities is guided, mainly, by identifying models that claim, tirelessly, the search for the breaking of all and any limit, a kind of apology to "human deification".

Among common, strong adrenaline experiences lived and reported by teenagers in the meetings, are practices such as: "holding the end of a car", "doing motorcycle Russian roulette", skate or bicycle races on slopped avenues, in a way that their stop and crossroads is difficult or even impossible. The state, however, that 
the pleasure they felt as they did such things was so intense that experiencing those dangerous situations was immeasurably enjoyable. These are the extreme sports of those poor teenagers.

According to the adolescents, as they experienced those "electrifying" (sic) situations they felt fear. They do not relate those actions, though, to the possibility of dying, but they fear becoming physically limited in case an accident happens and stop them or make it difficult for them to keep on participating in those "adventures". They say, openly: "I am not afraid of dying" (sic). The circumstances in which they state such a thing nears cynicism or despair: it is scary to hear a young person discredit life.

Freud (1916-1918/1948) characterized fear as a reaction to danger that would wake in a person a reflex to run away as a means of protection. Although fear is a beneficial feeling to human life, for it alerts a person of a possible threat to their life. It is for this reason that the lack of fear of death showed by those adolescents, at the same time it deeply intrigues, it also instigates curiosity in wanting to understand better the mental processes involved in this inconsequent search for pleasure under imminence of death. There already is a path here.

The lack of fear of death, explicated by those young people, may be related to what Bauman (2001) says about the feeling of immortality in contemporaneity. Currently there is a very strong and growing devaluation/ deflation in the sense of immortality. Such adjective was shifted from spatial and temporal dimensions to be directly associated to the notion of intensity. Thus, the immortal ceases to be what is not subject to death, that is, they exist as an object present in time and in space, infinitely, to take the disfiguring mask that was converted into immortal, because being intense, means being enthusiastic/passionate.

People whose egos Subjects are "destroyed but immortal", supported by a deceptively intense experience of "pleasure" in "immeasurable doses", showed a regressed functioning, maintained by the denial of the size of a destructive dimension of such "radicality", and its perverse conversion into something wonderful. The imminence of their own death is emptied of its true meaning to convert into everything that provides instant pleasure. So it is perfectly understandable the fear young people have to commit their physical power, and not death itself, for disability, actually means to "be dead". In their rush to collect "immortal" moments, everything is valid and allowed, even killing or dying. According to Kurz (2004), the indifference towards others in our society, also reflects the detachment to life itself, indifference to their own selves.

Living under the sign of infinity of the 'oceanic feeling'(Freud, 1930/1981) and in communion with the All, reports a negative condition in which individuals are immersed and therefore, the denial of limits and the effective finitude of the human being. It is under this mental functioning that individuals become vulnerable to seduction and stop adhering to identifying heroic models, imposed by the cultural industry. Why do the hegemonic interests glamourize the absence of limits that unites all individuals symbiotically, so as to become undifferentiated from each other?

Wisely, the adolescents of the Group of the Remnants do not have financial support to do extreme sports such as rappel, bungee jumping, gliding, etc., so that they would try the "risk adrenaline" with "modern safety equipment". However, despite the spread of the words "total security", the incidence of serious or even lethal accidents involving such persons in such practices is common knowledge. It is understood that the discourse of "security technology" is ideological, serving as marketing attribute to social classes that can finance such practices. In fact, even the whole "security technology" does not deny the risk. Additionally, it serves the purpose of familiarizing people with fear, repressing its dimension of denouncing of danger, thus weakening them.

According to the Freudian/Adorno conception, this is nothing, but the maintenance of individuals in regressive psychic condition of pseudo-individualization and massification, gestated by the irrationality of the 'oceanic feeling' "...Ahora que encuentra muy cerca alcanzar este ideal, casi ha llegado a convertirse él mismo en un dios... . El hombre ha llegado a ser, por así decirlo, un dios com prótesis" (Freud, 1930/1981, p.3034 - emphasis added).

As soon as the work with the Group of the Remnants began, it was possible, based on their reports, to understand they had been captured by the violence of those identifying models that reproduced, and 
certainly still do, with little discernment and criticism, what has been socially imposed. They are victims and accomplices of the process of social discrimination/ elimination.

The standardization of the individuals (Adorno \& Horkheimer, 1985) results from a mean process of social manipulation that leads to total elimination of differences and to the discernment disability. Standardized Individuals are fused together (symbiosis), equaling therefore, as to how to act, think, feel, relate to external/internal objects, etc., because they follow predetermined identification models, distributed mainly by the media. I mean, even the "core" of the inner life of the individual suffers from the disruptive influence of the social oppression that turns individuals into "death masks" (Adorno, 1986a).

Another moment when it was possible to realize the standardization in which adolescents are immersed, was one when one of them, (A.), "said he was going to buy a gun as a justification that it was the only way to be respected" (sic). It was tried to demonstrate to the Group that there were other ways to obtain respect from the others. The young man, however, insisted otherwise saying that "for them (the poor), respect is gotten only with the possession of a gun" (sic). The fact demonstrates how much adolescents had fallen into the social trap that has been transforming them into dangerous criminals. They cannot envision other alternatives but those threshed by society for them to follow. I mean: they have to get "respect" the same way they their "idols", intended to be venerated by them, did. It is the case of Fernandinho Beira Mar, so praised by the media. But this is a form of "social mobility possible to the impoverished class", "... closing, once more, the circle poverty-crime" (Coimbra, 2001, p.112).

Another example was the aggressor - aggressed logic in the episode when they were insulted at the movies. They supported that the offense they received when they were insulted by that lady, until they left the cinema: "we, the poor, do not have the right to go to the movies in a mall" (sic). Was it not that the expelling insult from that lady when they had happily entered the movie theater? As such adolescents seek to enforce their rights through violence, eventually legitimize the ideological discourse of the ruling class which is that impoverished individuals are really"dangerous/criminals", "and deserve", this way, criminalizing containment or even death. They showed their identification with the identifying model of a"dangerous class" (Coimbra, 2001) and, consequently, the internalization of social violence, by acting, exactly as the label impregnated with malignancy and dangerousness attributed to them. Not having watched the film and having supported, then the excluding attitude of the lady who "expelled from cinema, assaulting one of them".

There is no doubt that the internalization of social violence is explained by the internalization/ absorption of individuals regarding the identifying models that were socially proposed.

\section{The almost-impossibility of preserving life: Would that be the conclusion?}

Why can't these teenagers protect themselves from the evil action of prejudice, internalize their malign attributions and destroy themselves in complicity with those who brutalize them?

In order to better explain the type of violence to which we refer and to which these youngsters are exposed, it is worth Levisky (1998, p.79):

There is, nowadays, some kind of ideology going around that preaches that it is better to kill a "guttersnipe" today than to disturb society with one more criminal tomorrow. The massacre of the Candelária boys in Rio de Janeiro in 1993 only proves the existence of followers of this ideology, particularly in a Brazilian city whose 'violence is endemic' (Folha de São Paulo, 26/6/91). These are the extermination groups for children, organized in order to preserve the wellbeing of the civilized Brazilian society. This is the hypocrisy, the social effrontery of constituted authorities serving as a role model in a decadent society.

Thus, the subjectivities are immerse in the disseminated violence, internalized and reproduced by each and every individual of this society. Therefore, it is not only the Remnants that reproduce social violence by internalizing it in their psyche. They too reproduce this violence and, like many others, are subjected to these and to other forms of self-punishment.

It was not by chance that the first theme brought into discussion by the adolescents was of the violence, during all the time we were together, which 
permeated all the other themes discussed. They reported their own or their friends' stories, in which violence was always present in several different manners: addictions; fights, often times with the use of weapons; saying that "the thing is all about living dangerously" (sic), "living with adrenaline" (sic); practicing radical sports such as skateboarding, motorcycling and biking with radical maneuvers and/or using themselves as obstacles so that others could just over them with these; attacking each other with slaps, pinches and punches on the head, etc.

E., an adolescent, said that when he was questioned because of his behavior of punching people on their heads during school break he said: "when I was little, I got punched on the head... today, I've grown up, so I punch others on their heads"(sic). "The one who is hard on themselves acquires the right to do it on to others, and takes revenge for the pain they did not have the freedom to demonstrate and needed to repress" (Adorno, 1986b, p.39).

Although the expression of major intimacies were not allowed during the meetings with the Remnants, their existential suffering became clear, manifested through violent practices that attempted to hide such suffering. One example is the fact that the teenagers look for the academics of Phenix before going to the meeting rooms and talk, in a banal manner, about their "adventures" over the weekend: "hey, teacher, I've broken my arm but it was really nothing" (sic) or when they showed/exhibited sign of aggressions on their bodies as a result of involvements in fights and in the practice of the "radical sports".

In summary, it was found that, in a final analysis, teenagers end up reproducing what society expects from them: they are subservient and not emancipated, and proceeding this way, the segregation practices that they suffer will only act to stigmatize them, although not explicitly. By reproducing what society expects from them as a poor class, the teenagers create the justifications that are given for the prevailance of the prejudices that imprison them. By behaving according to what society expects from them, they become submissive and accomplices with the society that guilts them in a terrifying manner.

The "idea", disseminated by the mass means of communication about the naturalization (biological explanation) of violence, as if it were present in the blood of each individual of poor classes, treated as dangerous for the sake of being poor, is pointed out by Coimbra (2001) and becomes evident in a teenager's (Y.) reflection, when she writes about hatred: "it is a feeling that came out of out mothers' wombs: it is a challenge as it tries to dominate us..." (sic). Later, she expressed the internalized hatred and said: ".. the bullet can be for you, there is no escape, no hiding, it always finds you, and you know why? Hatred is inside you too!" (sic). There is evidence, thus, that the poor class itself does not react because it has in its core, in its mind, the conception that "it is dangerous by its own nature" and deserves to be punished.

It is necessary to always have in mind that the construction of ideas full of prejudice about individuals of classes that are less socially favored is highly mutilating of their autonomy process. Moreover, it requires the complicity of those who incorporate what is imputed onto them. The efficiency of the violence of the internalized prejudices only has its strength because it is supported by the adhesion of the ones who suffered such violence, even if unconsciously. The psychosocial massacre of these individuals can be understood in this way. However, we believe in the Human capacity to revert this process by means of resistance to these judgments, in the capacity individuals have to break the cycle poverty-marginality-dangerousness/ criminality.

It is through the use of reflexive integrity, bonding and supporting among men that subjectactions can be developed ("emancipatory education" Adorno,1995). For those who value life it is meaningful and nurturing to work in solidarity with teenagers that, just like the ones from the Group of the Remnants, suffer under the domain of powerful social prejudices. This is only possible when one loves themselves and believes in the life force and transformations of individuals. A human being can be a phoenix!

\section{References}

Abeche, R. P. C. (2003). Por trás das câmeras ocultas a subjetividade desvanece (Tese de doutorado não-publicada). Programa de Psicologia da Religião, Universidade Metodista de São Bernardo.

Adorno, T. (1986a). A indústria cultural. In F. Fernandes (Ed.), TheodorW. Adorno: Sociologia (pp.92-99). São Paulo: Ática. 
Adorno, T. (1986b). Educação após Auschwitz. In F. Fernandes (Ed.), Theodor W. Adorno: sociologia (pp.32-45). São Paulo: Ática.

Adorno, T. (1995). Educação e emancipação. São Paulo: Paze Terra.

Adorno, T., \& Horkheimer, M. A. (1985). Dialética do esclarecimento: fragmentos filosóficos. Rio de Janeiro: Jorge Zahar. (Originalmente publicada em 1947).

Agamben, G. (2007). Estado de exceção. São Paulo: Boitempo.

Bauman, Z. (1998). Modernidade e holocausto. Rio de Janeiro: Zahar.

Bauman, Z. (2001). Modernidade líquida. Rio de Janeiro: Jorge Zahar.

Bourquin, J. (2003). Delinqüência juvenil: punir ou educar? Lê monde Diplomatique. Recuperado em setembro 27, 2003, disponível em <http://www.diplo.com.br/aberto/ materia.php?id=343>.

Brandão, C. R. (Org.). (1981). Pesquisa participante. São Paulo: Brasiliense.

Brandão, C. R. (Org.). (1984). Repensando a pesquisa participante. São Paulo: Brasiliense.

Brasil. (1990). Estatuto da criança e do adolescente. São Paulo: Cortez.

Brasil. (2001). Código penal (39a ed.). São Paulo: Saraiva.

Caniato, A. M. P. (1997). A sociabilidade autoritária: comprometimento na individualização e para a cidadania. Psicologia em Estudo, 2(3), 109-130.

Caniato, A. M. P. Rodrigues, A., Silva, J., Quilice, K., Santos, L., \& Corazza, L. F., et al. (2002). Phenix: The daring of the erbirth of citizen subjectivity. Porto Alegre. Psicologia e Sociedade, 14(2), p.95-132.

Caniato, A. M. P. (2003). Da subjetividade sob sofrimento narcísico numa cultura da banalidade do mal. Recuperado em dezembro 29, 2004, disponível em <www.estados gerais.org/mundial_rj/download/5c_Caniato_180 50803_port.pdf>.

Caniato, A. M. P. (2007). A banalização da mentira como uma das perversões na sociedade contemporânea e sua internalização como destrutividade psíquica. Psicologia e Sociedade, 19(3), 96-107.

Caniato, A. M. P. (2008). A violência do preconceito: a desagregação dos vínculos coletivos e das subjetividades. Arquivos Brasileiros de Psicologia, 60(2), 20-31.

Carone, I. (2003). Adorno e a educação musical pelo rádio. Educação \& Sociedade, 24(83), 2-18.

Chaves, J. (1997). "Ficar com": um novo código entre os jovens. Rio de Janeiro: Revan.

Coimbra, C. M. B. (2001). Operação Rio: o mito das classes perigosas: um estudo sobre a violência urbana, a mídia impressa e os discursos de segurança pública. Niterói: Intertexto.

Cohn, G. (1986). Adorno e a teoria crítica. In G. Cohn. Sociologia (pp.7-30). São Paulo: Ática.
Crochik, J. L. (2005). Preconceito: relações com a ideologia e com a personalidade. Estudos de Psicologia (Campinas), 22(3), 309-319. doi: 10.1590/S0103-166X.

Cunha, A. G. (1982). Dicionário etimológico: nova fronteira da língua portuguesa. Rio de Janeiro: Nova Fronteira.

Dejours, C. (1999). A violência invisível: entrevista. Caros Amigos, 26, 16-17.

Freud, S. (1948). Introduccion al psicoanalisis. In S. Freud. Obras completas (pp.262). Madrid: Biblioteca Nueva (Originalmente publicado en 1916-1918).

Freud, S. (1981). El malestar en la cultura. In S. Freud. Obras completas (pp.3018-3067). Madrid: Biblioteca Nueva. (Originalmente publicado en 1930).

González Rey, F. (2005). Pesquisa qualitativa e subjetividade: os processos da construção da informação. São Paulo: Pioneira Thompson Learning.

Guinsberg, E. (2001). La salud mental en el liberalismo. Mexico: Plaza y Valdés.

Kurz, R. (2004). La globalización debe adaptarse a las necesidades de las personas, y no al contrario. Recuperado en mayo 22, 2004, disponible en <http//www.rebelion. org/sociales/040517kurz.htm>.

Leontiév, A. (1978). O homem e a cultura. In A. Leontiév. O desenvolvimento do psiquismo (pp.259-284). Lisboa: Horizonte Universitário.

Levisky, D. L. (1998). Adolescência: reflexões psicanalíticas. São Paulo: Casa do Psicólogo.

Lucchesi, I. (2002). Mídia e sedução sem encantamento. In Observatório da Imprensa. Rio de Janeiro. Recuperado em agosto 4, 2002, disponível em <http://www.observatorio daimprensa.com.br/ artigos/jd060320024.htm>.

Mariotti, H. (2000). A era da avareza: a concentração de renda como patologia bio-psico-social. Recuperado em agosto 16, 2003, disponível em <http://www.geocities.com/ complexidade/avareza.html $>$.

Martin, H. P., \& Schumann, H. (1999). Armadilhas da globalização (5ª ed.). São Paulo: Globo.

Martin-Baró, I. (1987). El latino indolente: carácter ideológico del fatalismo latinoamericano. In M. Montero (Coord.), Psicologia política latinoamericana (pp.135-162). Caracas: Panapo.

Sawaia, B. (1999). As artimanhas da exclusão: análise psicossocial e ética da injustiça social. Petrópolis: Vozes.

Shelp, D. (2003). Prazer e perigo. Veja, 1811, 70-78.

Thiollent, M. (1981). Crítica metodológica: investigação social e enquete operária ( $2^{\mathrm{a}}$ ed.). São Paulo: Polis.

Velho, G. (1987). Duas categorias de acusação na cultura brasileira contemporânea. In G. Velho. Individualismo e cultura: notas para uma antropologia da sociedade contemporânea (pp.59-68). Rio de Janeiro: Jorge Zahar.

Received on: 10/2/2011

Approved on: 9/5/2012 
